\title{
HEPATIC ADENOMA
}

\author{
Adenoma hepático \\ Daniel José SZOR, Mauricio URSOLINE, Paulo HERMAN
}

From the Departament of Gastroenterology, Faculty of Medicine, University of São Paulo, São Paulo, SP, Brazil.

HEADINGS - Hepatic adenoma. Surgery. Clinical treatment. Diagnosis. Pathophysiology. Molecular biology.
ABSTRACT - Background: Benign liver tumors, due to its relative easeness its imaging identification, have their incidence increasing in population in recent years, becoming frequent in the clinical picture and often a challenge for clinicians and surgeons. Doctors began to face dilemmas related to diagnosis in asymptomatic patients with liver nodules. Aim: Update the knowledge of hepatic adenomas due to the crescent diagnosis seen in the recent years. Methods: Was performed a literature review consulting Medline/PubMed, SciELO, Embase, Lilacs database with the following descriptors: hepatic adenoma, surgery, medical treatment, diagnosis, pathophysiology and molecular biology. Conclusion: The diagnosis of incidental asymptomatic lesions is a major dilemma in clinical practice because it brings intense distress for patients and their families, and often become a challenge for the physician or surgeon. Injury is of particular interest because it can provide both benign evolution or potentially lethal complications. Recently, its resection is no more mandatory; currently, more individualized treatment are required, aiming less morbidity. In light of new advances in molecular biology, the physician who diagnoses the lesion must identify the potential unfavorable evolution, and recognize cases who need more aggressive medical management.

\section{Correspondence: \\ Paulo Herman \\ E-mail: pherman@uol.com.br \\ Financial source: none \\ Conflicts of interest: none}

Received for publication: 10/12/2012

Accepted for publication: 26/04/2013

DESCRTTORES - Adenoma hepático. Cirurgia. Tratamento clínico. Diagnóstico. Fisiopatologia. Biologia molecular.
RESUMO - Introdução: Os tumores hepáticos benignos, devido à relativa facilidade na identificação através de exames de imagem, tiveram incidência crescente na população nos últimos anos, tornando-se quadro frequente na rotina clínica e muitas vezes um desafio para clínicos e cirurgiões. Logo, o médico passou a enfrentar dilemas relacionados ao diagnóstico e conduta nestes pacientes assintomáticos e portadores de nódulos hepáticos. Objetivo: Atualizar o conhecimento dos adenomas hepáticos frente à evolução ocorrida com seu conhecimento nos últimos anos. Método: Foi efetuada revisão da literatura em consulta na Medline/Pubmed, Scielo, Embase e Lilacs com cruzamento dos seguintes descritores: adenoma hepático, cirurgia, tratamento clínico, diagnóstico, fisiopatologia e biologia molecular. Conclusão: O diagnóstico incidental de lesões assintomáticas constitui grande dilema na prática clínica, pois traz intensa angústia para o paciente e seus familiares, e muitas vezes tornam-se um desafio para o clínico ou cirurgião. É lesão de particular interesse, pois pode apresentar evolução tanto benigna como complicações potencialmente letais. O adenoma hepático deixou recentemente de ser lesão de ressecção obrigatória; atualmente, adota-se conduta mais individualizada, visando menor morbimortalidade. À luz dos novos avanços da biologia molecular, cabe ao médico que o diagnostica identificar aqueles com potencial evolução desfavorável, para que nesses seja empregada conduta mais agressiva.

\section{INTRODUCTION}

Advances in radiology imaging tests become more sensitive 4 and specific, as well as with higher availability at lower costs. Ultrasonography is a great example, its routine use has brought benefits and raised questions about diseases previously underdiagnosed.

The benign liver tumors, because of their relative easeness in identification by imaging tests, such as ultrasound, had increasing incidence in the population in recent years, becoming frequent in the clinical picture and often a challenge for clinicians and surgeons. Soon, the doctor began to face dilemmas related 
to diagnosis and these patients were asymptomatic or had liver nodules.

The more frequent benign tumors are hepatic hemangioma, focal nodular hyperplasia and hepatic adenoma. Among these is highlighted the hepatic adenoma - third more frequent -, with risk of bleeding and malignant transformation, thus, requiring more aggressive approach.

This review of the hepatic adenoma aims to analyze the prevalence, epidemiology, pathophysiology, molecular classification and treatment.

\section{METHOD}

Literature review was based on Medline/PubMed, SCIELO, EMBASE, LILACS search with the following headings: hepatic adenoma, surgery, medical treatment, diagnosis, pathophysiology and molecular biology.

The hepatic adenoma $(\mathrm{HA})$ is a rare benign solid tumor with incidence of 1:100,000, affecting mainly women, with the highest prevalence in reproductive age, being lonely in $80 \%$ of cases, and located in the right hepatic lobe with greater frequency ${ }^{1}$. Its consistency is soft, well defined and with little or no fibrous capsule. The tumor is supplied by small arterioles with thin walls, containing no portal element, as biliary ducts. The liver around the lesion often is fatty, with no relationship to cirrhosis.

Regarding histology, hepatocytes are in normal size, with normal cytoplasm contents, and can have greater amount of glycogen or fat. Nuclear atypia and mitoses are rarely seen, but, when found, should raise suspicion of malignant transformation. Degenerative changes, such as sinusoidal dilatation, peliosis and infarcts are common and can result in fibrotic or edematous areas ${ }^{2}$.

The hepatic adenomatosis is a rare disease characterized by the presence of 10 or more tumors; are excluded from this diagnosis patients who have history of glycogen storage or oral use of contraceptives, since these factors alone stimulate the appearance of tumor .

\section{Pathophysiology}

The following factors are closely related to the appearance of the HA:

\section{Oral use of contraceptives}

This factor is responsible for the increase in incidence over the past 40 years, due to the increased consumption by women of childbearing age. Before the $60 \mathrm{~s}$, the HA was rarely described. With the advent of use of oral contraceptives the incidence increased, a fact already reported by Baum in $1973^{3}$. Subsequent studies also determined that the effect was dose and duration related $^{4}$, and evolution itself will also be affected by medication. Its use increases the size, number and risk of bleeding, as well as the discontinuation of oral contraceptives can determine the regression ${ }^{5}$.

No justification in the literature is found about the exact contraceptives effect on the appearance of HA. Two studies were performed in order to investigate estrogen receptors in the disease; their results were controversial, since one demonstrated the presence of receptors in one third of cases $^{6}$ while the other did not find such relation?

\section{Use of anabolic steroids}

Used primarily for the treatment of Fanconi syndrome or to gain muscle mass, anabolic steroids do similarly what a contraceptive does. Its use predisposes the emergence and growth of $\mathrm{HA}$, as well as, the discontinuity can lead to regression ${ }^{8}$.

\section{Diseases of glycogen accumulation}

Occurs in individuals younger than 20 years, with a higher proportion among males, and typically multiple adenomas. The way glycogenosis predisposes to the appearance of the HA is still undetermined. The incidence ranges from 25 to $50 \%$ in glycogenosis type I and III, respectively ${ }^{9}$. The adoption of specific diet, as well as control serum insulin, glucose and glucagon can lead to regression of the condition.

\section{Clinical presentation}

$\mathrm{HA}$ can be detected in different situations, since its clinical spectrum is variable.

\section{Incidental}

Is the most common presentation. The diagnosis is made while radiological investigation is directed to other disease or condition, as in the case of ultrasound during pregnancy or to evaluate cases of dyspepsia or urinary tract stones. Important to remember that in these cases the patient has no symptoms related to HA.

\section{Clinical and laboratory findings}

Clinically, generally they are asymptomatic. Slight abdominal pain located in the epigastrium and in right hypochondrium, and bloating are the most common encountered symptoms. Elevations of GGT (gamma glutamyl transferase) and alkaline phosphatase may be present. In cases with malignant transformation, it can be observed elevation of serum alpha-fetoprotein .

\section{Emergency}

One complication is rupture followed by hemoperitoneum. This complication occurs in 20 to 30 $\%$ of cases, especially in tumors greater than $5 \mathrm{~cm}$. The patient will present bleeding acute abdomen, requiring emergency treatment. Dokmak ${ }^{1}$ in his series of 122 resected $\mathrm{HA}$, reports a $20 \%$ rate of bleeding, and $10 \%$ as acute hemorrhagic complication, related to tumors larger than $5 \mathrm{~cm}$.

Despite the rupture and hemoperitoneum be potentially lethal, rates of hemodynamic instability in 
these cases are low. Since mortality in hepatic resection in emergencial context can reaches $8 \%$, it may require hemodynamic stabilization and tumor embolization through hepatic artery using interventional radiology. This procedure decreases the tumor facilitating eventual elective resection or even allowing conservative treatment, due to the fact that reducting in tumor size decreases the chances of rebleeding; rarily coexist bleeding with malignancy.

\section{Diagnosis}

Importantly, HA by not showing typical radiological investigation, cannot have diagnosis confirmed by any imaging exam currently available; it can be, at most, strongly suspected. The definitive diagnosis is made by pathological examination, obtained by biopsy or resection. So, it is up to radiology to suggest the diagnosis and assist in the differentiation among the various types of liver nodules.

Ultrasonography of the abdomen sometimes fails to differentiate it from other benign or even malignant tumors. Can detect well-defined lesion, heterogeneous, with areas of intratumoral hemorrhage (calcifications and heterogeneous appearance) or areas with necrosis (hyperechogenicity) $^{10}$.

Computed tomography of the abdomen reveals well-defined lesion with irregular hypervascularization after contrast administration. Generally has a heterogeneous aspect due to hemorrhage, necrosis and fibrosis ${ }^{11}$.

Resonance reveals the same aspects of CT also showing hyper-signal intensity on $\mathrm{T} 1$ and $\mathrm{T} 2$. Can identify the presence of fat in the nodule, strongly suggesting that it is $\mathrm{HA}^{12}$.

The isotopic mapping using iminodiacetic acid derivatives labeled with 99mTc (DISIDA) reveals lesions that captures the radiotracer, with slow elimination in comparison to the surrounding parenchyma. The focal nodular hyperplasia shows the same finding in DISIDA. To distinguish between the HA and focal nodular hyperplasia, scintigraphy with colloidal sulfur which marks the cells of the reticuloendothelial system in the liver represented by Kupffer cells -, should be used. By not having Kupffer cells or present them in nonfunctioning state, $\mathrm{HA}$ has no appearance in scintigraphy ${ }^{13}$. Already focal nodular hyperplasia, which have functioning Kupffer cells, can have the diagnosis made through it.

The transparietal biopsy is considered conduct of exception, since bleeding may occur after biopsy in hypervascular nodes. Is only indicated when imaging studies do not confirm the diagnosis. Recent studies show diagnosis, using only imaging, in $87 \%$ of cases $^{14}$.

In summary, the diagnosis of benign liver tumor is important, since the treatment may be opposite, varying between resection and monitoring. Herman et $\mathrm{al}^{15}$ reported rate of diagnosis of $\mathrm{HA}$ in $90 \%$ of cases through imaging and in $77 \%$ in focal nodular hyperplasia. Concluded that, in doubtful cases, biopsy may be needed.

\section{Complications}

HA can have unfavor evolution in two situations: bleeding and malignant transformation.

Hemorrhage is the most common, being intratumoral or spontaneous rupture in cavity, causing hemoperitoneum. Cho et $\mathrm{al}^{16}$ in a retrospective study with 41 patients showed 12 cases (29\%) of hemorrhage, and three with acute abdominal hemorrhage. Diameter of $5 \mathrm{~cm}$ was present in 11 of the 12 tumors.

There are no longitudinal studies in malignancy. Deneve et. $\mathrm{al}^{17}$ in retrospective analysis of 124 cases reported rate of malignancy in $4 \%$ of cases, with a minimum diameter of $8 \mathrm{~cm}$. Dokmak et $\mathrm{al}^{1}$ described $10 \%$ of malignancy in their series, highlighting only one case less than $8 \mathrm{~cm}$, and also highlighting the increased incidence of malignancy in men.

\section{Treatment}

Due to complications, possibly lethal, classically HA has surgical resection after diagnosis. With better knowledge of the disease, the development of surgical techniques and molecular biology, some changes in behavior are currently adopted. They are:

a) resection of all tumors with more than $5 \mathrm{~cm}$, even in patients with adenomatosis;

b) laparoscopic resection for tumors with surgical indication in segments anatomically favorable, as in the left lateral sector (segments 2 and 3 ) and 4b, 5, 6 , benefit from laparoscopic resection ${ }^{15}$; care must be taken towards not simply expand the surgical indication for the lower invasiveness of the procedure;

c) new molecular biology investigation, allows to identify which tumors are more or less likely to progress to malignancy.

Due it is rare tumor, the available studies do not yet have great quantitative significance, but the results currently available are enough to raise controversy over the best approach to be adopted, ie, observe or resect the tumor.

The trend in larger centers worldwide ${ }^{1}$, and in the surgical service of authors, resection is indicated in symptomatic HA or in the ones greater than $5 \mathrm{~cm}$ because of the risk of malignancy; smaller asymptomatic lesions are observed and the use of oral contraceptives is discontinued.

In the near future, the best approach will be based according to the molecular biology of the tumor, searched through histological analysis of tissue obtained by transparietal biopsy.

\section{Molecular biology}

Bioulac Sage on paper published in $2007^{18}$ divides hepatic adenomas into four subtypes according to genetic and inflammatory aspects. Describes two genetic alterations: the inactivation of hepatocyte 
nuclear factor $\alpha 1$ (HNF $\alpha 1$ ) and mutation of $\beta$-catenin.

The first subgroup (40\%) is characterized by the biallelic inactivation of $\mathrm{HNF \alpha 1}$; in $85 \%$ of the cases the inactivation is somatic and $15 \%$ is in part somatic and in part hereditary. It is associated with marked steatosis and metabolic disease, as well as the absence of cytologic or inflammatory reactions. A mutation in the gene HNF $\alpha 1$ and its relationship with malignancy is present, but is rare (15\%).

The second subgroup (10\%) is characterized by a mutation in the $\beta$-catenin and associated with malignant transformation. The mutation is characterized by a deletion of exon 3, or changes in aminoacid chain leading to changes in phosphorylation. It is more common in males; they have cytoplasmic changes and lower rates of steatosis.

The third subgroup (40\%) shows no genetic changes and is characterized by inflammatory changes such as sinusoidal dilatation, and dystrophic vessel ductular reaction. They replace the previous so-called group of focal nodular teleangiectasic hyperplasia.

The fourth subgroup (10\%) includes patients whose tumors did not exhibit genetic or inflammatory diseases.

Nowdays, is proposed the treatment be based on molecular biology of the tumor, since changes were identified that can predict the malignancy. In reference to bleeding risk, no predictor fator, whether molecular or histopathological, was identified.

\section{CONCLUSION}

The incidental diagnosis of asymptomatic lesions is a major dilemma in clinical practice because it brings intense distress for patients and their families, and often become a challenge for the physician or surgeon. The $\mathrm{HA}$ is of particular interest because it can provide both, benign evolution or potential lethal complications. Thus, it is recommended that it should be treated in a specialized center. The HA recently left to be a lesion of mandatory resection; currently takes up more individualized direction, diminishing morbidity. In light of new advances in molecular biology, the physician who diagnoses must identify the HA with potential unfavorable evolution, using in them more aggressive teatment.

\section{REFERENCES}

1. Dokmak $S$, Paradis $V$, Vilgrain $V$, Sauvanet $A$, Farges $O$, Valla $D$, Bedossa P, Belghiti J. A single-center surgical experience of 122 patients with single and multiple hepatocellular adenomas. Gastroenterol 2009;137: 1698-1705.
2. Bioulac-Sage $P$, Rebouissou $S$, Thomas $C$, Blanc JF, Saric J, Sa Cunha A, Rullier A, Cubel G, Couchy G, Imbeaud S, Balabaud C, Zucman-Rossi J. Hepatocellular adenoma subtype classification using molecular markers and immunohistochemistry. Hepatology 2007; 46: 740-748.

3. Baum, JK, Bookstein, JJ, Holtz, F, Klein, EW. Possible association between benign hepatomas and oral contraceptives. Lancet 1973; 2:926.

4. Epidemiology of hepatocellular adenoma. The role of oral contraceptive use. Rooks JB; Ory HW; Ishak KG; Strauss LT; Greenspan JR; Hill AP; Tyler CW Jr JAMA 1979 Aug 17;242(7):6448.

5. Regression of liver cell adenomas associated with oral contraceptives. Edmondson HA; Reynolds TB; Henderson B; Benton B Ann Intern Med 1977 Feb;86(2):180-2.

6. Sex and androgenic steroid receptor expression in hepatic adenomas. Cohen C; Lawson D; DeRose PB Hum Pathol 1998 Dec;29(12):1428-32.

7. Expression of steroid hormone receptors in benign hepatic tumors. An immunocytochemical study. Masood S; West AB; Barwick KW Arch Pathol Lab Med 1992 Dec;116(12):1355-9.

8. Multiple hepatic adenomas after long-term therapy with testosterone enanthate. Review of the literature. Carrasco $D_{\text {; }}$ Prieto M; Pallardo L; Moll JL; Cruz JM; Munoz C; Berenguer J J Hepatol 1985;1(6):573-8.

9. Hepatocellular adenomas in glycogen storage disease type I and III: a series of 43 patients and review of the literature Labrune P; Trioche P; Duvaltier I; Chevalier P; Odievre J Pediatr Gastroenterol Nutr 1997 Mar;24(3):276-9.

10. Hepatocellular adenoma: color Doppler US and pathologic correlations. Golli M; Van Nhieu JT; Mathieu D; Zafrani ES; Cherqui D; Dhumeaux D; Vasile N; Rahmouni A. Radiology 1994 Mar;190(3):741-4.

11. Hepatic adenomas: imaging and pathologic findings. Grazioli L; Federle MP; Brancatelli G; Ichikawa T; Olivetti L; Blachar A Radiographics 2001 Jul-Aug;21(4):877-92; discussion 892-4.

12. Hepatic adenoma: MR characteristics and correlation with pathologic findings Paulson EK; McClellan JS; Washington K; Spritzer CE; Meyers WC; Baker MAJR Am J Roentgenol 1994 Jul;163(1):113-6.

13. Accumulation of technetium-99m sulfur colloid by hepatocellular adenoma: scintigraphic-pathologic correlation. Lubbers PR; Ros PR; Goodman ZD; Ishak KG AJR Am J Roentgenol 1987 Jun;148(6):1105-8.

14. Laumonier H, Bioulac-Sage P, Laurent C, Zucman-Rossi J, Balabaud $C$, Trillaud $\mathrm{H}$. Hepatocellular adenomas: magnetic resonance imaging features as a function of molecular pathological classification. Hepatology 2008; 48: 808-818.

15. Herman P, Pugliese V, Machado MA, Montagnini AL, Salem MZ, Bacchella T, D'Albuquerque LA, Saad WA, Machado MC, Pinotti HW. Hepatic adenoma and focal nodular hyperplasia: differential diagnosis and treatment. World J Surg 2000; 24: 372-376.

16. Cho SW, Marsh W, Steel J, Holloway Se, Heckman JT, Ochoa Er, Geller DA, Gamblin C. Surgical management of hepatocellular adenoma: take it or leave it? Ann Surg Oncol 2008; 15: 2795-2803.

17. Deneve JL, Pawlik TM, Cunningham S, Clary B, Reddy S, Scoggins CR, Martin RC, D'Angelica M, Staley CA, Choti MA, Jarnagin WR, Schulick RD, Kooby DA. Liver cell adenoma: a multicenter analysis of risk factors for rupture and malignancy. Ann Surg Oncol 2009;16: 640-648.

18. Bioulac-Sage P, Rebouissou S, Thomas C, Blanc JF, Saric J, Sa Cunha A, Rullier A, Cubel G, Couchy G, Imbeaud S, Balabaud C, Zucman-Rossi J. Hepatocellular adenoma subtype classification using molecular markers and immunohistochemistry. Hepatology 2007; 46: 740-748. 